\title{
Feeding Food Wastes to Swine 1
}

\section{L. Westendorf and R.O. Myer ${ }^{2}$}

The feeding of food waste or garbage to swine and other livestock animals is a common practice throughout the world and is often concentrated around metropolitan centers. Food plate waste (formerly referred to as garbage) may be fed to other livestock species, but has most often been used as a source of feed for swine. High disposal costs and fees encourage the feeding of food/plate waste.

Food waste can be defined as any edible material or byproduct that is generated in the production, processing, transportation, distribution, or consumption of food. The primary waste products fed to swine are plate and kitchen waste, bakery waste, and food products from grocery stores. The primary sources of plate waste are restaurants, institutions, schools, and to a small degree, households. Food waste originating from restaurants, institutions, and schools has traditionally been referred to as garbage and has been regulated as such. According to the USDA there are over 2,200 licensed garbage feeders in the United States and nearly 3,000 in Puerto Rico (USDA-APHIS, VS, 1995). For the purpose of this article, the term food waste will be used to refer to all food wastes, including plate waste, kitchen or table scraps, garbage or swill and all food residuals discarded after serving.
Feeding food waste to swine has been common in the United States, especially in rural areas adjacent to major metropolitan areas. This practice has declined in recent years because of stricter federal, state, and local laws regulating animal health, transportation, and the feed usage of food waste. Although the feeding of raw (unprocessed) food waste to animals has been limited, there are still many states that allow it in some form.

\section{Treatment of Food Waste}

Food waste to be fed to pigs must be heat treated as mandated by the 1980 Swine Health Protection Act. This is done to reduce the risk of foreign animal diseases in swine and to eliminate any other harmful pathogens. These diseases may be spread to other livestock or humans if swine consume contaminated meat in improperly treated food waste. These diseases include hog cholera, foot and mouth disease, African swine fever, and swine vesicular disease. Other pathogens of concern are salmonella, campylobacter, trichinella, and toxoplasma. Food waste must be cooked as described below:

a) Food waste shall be heated throughout at boiling $\left(212^{\circ} \mathrm{F}\right.$ or $100^{\circ} \mathrm{C}$ at sea level) for 30 (thirty) minutes; and, b) it shall be agitated during

1. This document is AS143, one of a series of the Animal Science Department, Florida Cooperative Extension Service, Institute of Food and Agricultural Sciences, University of Florida. Original publication date May 17, 2004. Visit the EDIS Web Site at http://edis.ifas.ufl.edu.

2. Westendorf, M.L., Associate Professor, Extension Animal Scientist, Rutgers University, New Brunswick, NJ, and Myer, R.O., Professor of Animal Science, University of Florida, NFREC Marianna.

The Institute of Food and Agricultural Sciences (IFAS) is an Equal Employment Opportunity - Affirmative Action Employer authorized to provide research, educational information and other services only to individuals and institutions that function without regard to race, creed, color, religion, age, disability, sex, sexual orientation, marital status, national origin, political opinions or affiliations. For information on obtaining other extension publications, contact your county Cooperative Extension Service office. Florida Cooperative Extension Service / Institute of Food and Agricultural Sciences / University of Florida / Larry R. Arrington, Interim Dean 
cooking, except in the steam cooking equipment, to ensure that the prescribed cooking temperature is maintained throughout the cooking container for the prescribed length of time.

There are two methods generally preferred for the heat treatment of food waste: direct fire, and steam injection (USDA-APHIS, VS, 1990). The direct fire method heats the food waste with flames that come in direct contact with a cooking vat that is stirred regularly. For larger operations, a steam injection method is used. This involves injecting steam into the bottom of a load of food waste so that it is evenly heated as steam percolates through the food waste.

It is the presence of meat in food waste that necessitates cooking; all table or plate scraps resulting from the handling, preparation, cooking, or consumption of food require cooking before feeding to swine (except for those produced and fed upon household premises). The act does not require the cooking of non-meat food waste or byproduct items (eg. bakery waste, vegetable waste, etc.).

The 2001 outbreak of Foot and Mouth Disease (FMD) in England has heightened the concerns about feeding food waste. Texas, a leading food waste feeding state, has recently banned the feeding of food waste because of FMD. The recent outbreak of FMD in the UK originated on a "food-waste-feeding" swine farm where contraband meat had been fed.

\section{Nutritive Value of Food Waste}

When fed properly, food waste can be a nutritious food source for swine. Even so, in comparison to commercial swine rations, food waste has a lower dry matter (DM) content, which may decrease nutrient intake and limit performance. Most swine fed exclusively on food/plate waste attain maximum gains of about one pound per day, but to achieve this, swine must consume food waste in larger quantities (as-fed basis) than they would commercial swine feed.

Food waste samples collected from New Jersey farms (Table 1) averaged in excess of $20 \%$ crude protein and over $25 \%$ fat (dry basis; Westendorf et al., 1999). These farms collected food waste from institutions (restaurants, casinos, military bases, hospitals, and nursing homes) and often supplemented with other food wastes (byproducts) such as bakery, fish cannery, or vegetable processing wastes. Fiber levels were low and most minerals were borderline to adequate, for growing pigs. However, the low DM (average, 27\%) and the high variability of nutrients (coefficients of variation often near or in excess of $100 \%$ ) were significant limitations. Essential amino acids were, on average, equal to or above National Research Council (NRC) recommendations required for growing pigs, with the possible exception of lysine which was slightly low on several of the farms tested. Food waste, although often of ample nutritional quality, is limited by its low DM and variable nutrient content, and should be monitored regularly and supplemented accordingly in practical feeding situations The samples in the 1995 survey also indicated that there was significant within-source variation as well as between-source variation.

It is difficult to predict intake when pigs are fed wet food waste. Not only will water content limit intake, but the level of contamination with other materials and the kinds of food waste fed will also affect consumption. Most feed intake research with pigs fed food waste has been with pigs in the range of 50 to 250 pounds. Food-waste-fed pigs are often fed to a finishing weight of 400 pounds or greater. Estimates of intake range from about 8-10 pounds (as-fed) per pig per day for pigs under 100 pounds to 20 pounds or greater for 250 -pound pigs. These values are from pigs fed institutional food waste that is between 20 and 25\% DM (Westendorf et al., 1998).

To achieve good daily weight gains, the feeding of supplemental grain (e.g. ground corn) may be desirable. Research conducted in New Jersey indicated that it is possible to obtain growth rates almost as good as those of pigs fed a traditional dry diet when food waste is supplemented with a ground corn premix. The results of this research are summarized in Table 2. Other research has found variable effects upon carcass quality when food waste is fed. Meat from food waste pigs was acceptable (Westendorf et al., 1998) when sampled by a consumer panel to determine pork flavor and texture. There were consumer differences in taste intensity, 
flavor, and texture, but overall flavor preference was not significantly different between food-waste-fed and control-fed pigs. The main concern with meat from food-waste-fed pigs has been with soft carcass fat, but these results have been variable.

\section{Processed Food Waste}

Development of new technologies to process food waste is a major need for food waste feeding. The NRC (1983) report, "Underutilized Resources as Animal Feedstuffs," discussed some of the methods used for processing fruit and vegetable waste; dehydration, pressing, screen separation, and an activated sludge process. Some other possibilities discussed in the NRC (1983) report, include ensiling and the use of chemicals such as sodium hydroxide, or the use of organic acids such as propionic or formic acid for preservation.

In Florida trials with a dehydrated restaurant waste blended with concentrate feeds, Myer et al. (1999) found good results at diet inclusion rates up to $80 \%$ of the blended product. New processing practices that reduce moisture content may make it easier to feed food waste, yielding a longer shelf life, and easier incorporation into commercial diets. The variability of food waste composition (high coefficients of variation) highlights the difficulty in including food waste in contemporary swine diets. Processes such as pelleting, dehydrating, extruding, or rendering will mix and heat the product more efficiently resulting in a more uniform, more stable, safer product. Some of the issues that will influence new processing techniques are regulatory in nature, such as whether processed food waste meets the requirements of the Swine Health Protection Act (1980), or whether the Food and Drug Administration should regulate these processes.

\section{Feeding Guidelines}

As the nutrient analysis in Table 1 makes clear, wet food waste, in spite of its otherwise acceptable nutrient content, is extremely variable. The following guidelines should be followed when feeding wet food waste:

1. Conduct regular nutrient analysis. Although diets will not be balanced in the traditional sense, this will help in determining deficiencies and implementing supplementation strategies. Consult your local county extension agent for location of nearby laboratories.

2. Supplement wet food waste with a dry feed such as ground corn to improve animal performance. Consider including a commercial vitamin/mineral premix with the corn.

3. Many pigs on food waste farms come in as feeder pigs. Starting them directly on food waste could be disastrous. They should be slowly adapted to food waste in the diet. Use a medicated complete starter feed when starting pigs on feed.

4. Avoid trashy food waste such as might come from a restaurant. Collect where source separation is practiced. Supermarkets and institutions may be the best at source separation.

5. Avoid feeds that are too wet. Low dry matter will result in lower dry matter intake and slower gains.

6. Follow cooking regulations if food waste contains meat or meat byproducts.

Dry or processed products can be fed similarly to other dry byproducts that are added in the diet. These should be sampled regularly for nutrient content to control variability.

\section{References}

Myer, R. O., J. H. Brendemuhl, and D. D. Johnson. 1999. Evaluation of dehydrated restaurant food waste products as feedstuffs for finishing pigs. J. Anim. Sci. 77:685.

NRC. 1983. Underutilized Resources as Animal Feedstuffs. National Academy Press. Washington D.C.

USDA-APHIS, VS. 1995. Risk Assessment Focus: Produce Questionnaire. Swine waste feeder profile reveals types, sources, amounts, and risks of waste fed. United States Department of Agriculture Animal and Plant Health Inspection Service, Veterinary Services. Center for Epidemiology and Animal Health. Fort Collins, CO. 
USDA-APHIS, VS 1990. Heat-Treating Food

Waste -- Equipment and Methods. USDA Animal and Plant Health Inspection Service, Veterinary Services. Program Aid No. 1324.

Westendorf, M, L., Z. C. Dong, and P. A. Schoknecht. 1998. Recycled cafeteria food waste as a feed for swine: nutrient content, digestibility, growth, and meat quality. J. Anim. Sci. 76:3250.

Westendorf, M. L., T. Schuler, and E. W. Zirkle. 1999. Nutritional quality of recycled food plate waste in diets fed to swine. Prof. Anim. Sci. 15(2):106-111. 
Table 1. Average composition of food plate waste fed on sample farms.

\begin{tabular}{|c|c|c|c|c|c|}
\hline Item $^{*}$ & $\begin{array}{l}\text { Sample } \\
\text { Size }\end{array}$ & Mean & $\begin{array}{l}\text { Standard } \\
\text { Deviation }\end{array}$ & $\begin{array}{l}\text { Coefficiant of } \\
\text { Variation }\end{array}$ & Range \\
\hline Dry Matter,\% & 63 & 27.0 & 5.2 & 19.3 & 13.0 to 39.6 \\
\hline Crude Protein,\% & 63 & 20.8 & 5.7 & 27.5 & 13.6 to 37.7 \\
\hline Crude Fat, $\%$ & 63 & 26.3 & 8.0 & 30.4 & 9.1 to 46.9 \\
\hline Fiber (ADF) \% & 62 & 6.3 & 2.6 & 41.2 & 2.4 to 15.3 \\
\hline Ash,\% & 63 & 6.2 & 2.2 & 35.3 & 3.0 to 16.4 \\
\hline $\mathrm{Ca}, \%$ & 63 & 0.92 & 1.02 & 111.1 & 0.06 to 6.33 \\
\hline $\mathrm{P}, \%$ & 63 & 0.64 & 0.46 & 72.1 & 0.12 to 2.18 \\
\hline $\mathrm{Mg}, \%$ & 63 & 0.08 & 0.03 & 34.8 & 0.03 to 0.13 \\
\hline $\mathrm{Na}, \%$ & 63 & 1.04 & 0.37 & 35.5 & 0.63 to 1.79 \\
\hline $\mathrm{K}, \%$ & 63 & 0.83 & 0.43 & 51.6 & 0.13 to 2.01 \\
\hline $\mathrm{Cu}, \mathrm{mg} / \mathrm{kg}$ & 54 & 17.3 & 23.5 & 136.4 & 1.4 to 164.6 \\
\hline $\mathrm{Fe}, \mathrm{mg} / \mathrm{kg}$ & 63 & 441 & 314 & 71 & 78 to 1778 \\
\hline $\mathrm{Zn}, \mathrm{mg} / \mathrm{kg}$ & 63 & 63 & 201 & 321 & 10.6 to 1621 \\
\hline $\mathrm{Mn}, \mathrm{mg} / \mathrm{kg}$ & 54 & 21.0 & 15.6 & 74.4 & 5.7 to 58.4 \\
\hline
\end{tabular}

Table 2. Supplementation of food waste diets fed to pigs.

\begin{tabular}{||c|c|c||}
\hline \hline Treatment $^{\text {a }}$ & \multicolumn{1}{|c||}{$\begin{array}{c}\text { Grower } \\
\text { ADG,lb }\end{array}$} & \multicolumn{1}{c||}{$\begin{array}{c}\text { Finisher } \\
\text { ADG, lb }\end{array}$} \\
\hline 1 & $1.80^{\mathrm{b}}$ & $2.18^{\mathrm{b}}$ \\
\hline 2 & $1.45^{\mathrm{c}}$ & $1.98^{\mathrm{b}}$ \\
\hline 3 & $1.34^{\mathrm{c}}$ & $1.69^{\mathrm{c}}$ \\
\hline 4 & $1.01^{\mathrm{d}}$ & $1.36^{\mathrm{d}}$ \\
\hline \multicolumn{2}{|c|}{} \\
\hline $\begin{array}{l}\text { aPigs given Treatment 1 received a corn and soybean-meal diet ad libitum; } \\
\text { Treatment 2 received ad libitum food waste plus a corn premix limited to } \\
50 \% \text { of Treatment 1 intake; Treatment 3 received ad libitum food waste plus } \\
\text { a corn premix limited to 25\% of Treatment 1 intake; and Treatment 4 } \\
\text { received only ad libitum food waste. The dietary treatments were formulated } \\
\text { assuming protein needs would be met by food waste and energy would be } \\
\text { limiting in food waste diets. (Westendorf et al., 1998). } \\
\text { bcd } \text { Means in the same column with a different superscript differ (P<.05). }\end{array}$ \\
\hline \hline
\end{tabular}

